\title{
L'effet de réel revisited: Barthes and the affective image
}

\author{
Sirkka Knuuttila \\ Institute for Art Research, Comparative Literature, \\ P.O. Box 3, 00014 University of Helsinki, Finland \\ e-mail: sirkka.knuuttila@welho.com
}

\begin{abstract}
This article addresses Barthes's development from a structuralist semiotician towards an affectively responding reader in terms of 'postrational' subjectivity. In light of his whole oeuvre, Barthes anticipates the understanding of emotion as an integral part of cognition presented in contemporary social neuroscience. To illustrate Barthes's growing awareness of the importance of this epistemological move, the article starts from his textual 'reality effect' as a critical vehicle of realist representation. It then shifts to his attempt at conceptualising an affective reading which resists the universalising idea of one ideologically determined signified. Barthes's progress towards embracing the actual reader's embodied self-feeling is prompted by two conceptual milestones: the obtuse meaning found in cinematic stills, and the experience of punctum felt in photos. In light of his lectures in the Collège de France, Barthes substitutes the Husserlian disembodied method of introspection with the Chinese $w u$-wei as a reading practice. As a result, his Zen-Buddhist concentration on bodily feelings elicited by visual/verbal images becomes a method capable of creating a fruitful link between language and wordless cognition. Finally, the article proposes an idea of the 'embodied reality effect' by reading affectively two similar scenes interpreted by the early and late Barthes himself.
\end{abstract}

I have a disease: I see language. Roland Barthes ${ }^{1}$

1 Barthes 1977: 161. 


\section{Sirkka Knuuttila}

When Roland Barthes in 1968 gave the description of Charlotte Corday in prison as a typical example that conveys l'effet de réel in Michelet's Histoire de France, ${ }^{2}$ he left the problem of the lost signified open for further explorations. For Barthes, the peculiar effect of a realistic discourse is a "direct collusion of the signifier and the referent" (1986a: 147), while the signified is entirely turned out from the signification process. Seen in the perspective of his whole oeuvre, for Barthes the nature of the signified is a nodal centre in the mediation process of 'reality', ${ }^{3}$ which he has approached ever since in numerous ways and theoretical frames. Especially when adopting the Kristevian notion of signifiance in Le troisième sens in 1973, he orients towards the bodily sensing of images. Also his demand of a theory of reading verbal and visual signs in Sur la lecture published in 1976, supposes new answers to be found with a reformulated notion of a reading experience. But what is most exciting for the purposes of this essay is his proposed answer to the problem of the lost signified - an absent content - from a temporal perspective to reality in La chambre claire, published originally in 1980. He makes it, for instance, by musing affectively before the photograph of Lewis Payne, who was prosecuted for an attempted assassination of the Secretary of the State W. H. Seward (Barthes 1981: 95-96). Strikingly, just like Corday, Payne is sitting in prison just before his execution and posing not for a painter, but for a photographer.

The similarity of the two images of Corday and Payne is the starting point for this essay by revealing for me the late Barthes's deep devotion to the bodily experience in reading. My purpose is to illuminate Barthes as one of those thinkers who, besides understanding the experience of image/text as a culturally mediated rhetoric construction, challenges the very nature of the notion of 'rational' by taking the corporeally lived, emotional aspect of the experience as an integral component of signification.

Throughout his entire career, Barthes addresses the questions of body and affect in relation to the problem of textual referentiality; the 'text' referring extensively to all cultural signifying systems, including

\footnotetext{
2 The original scene can be found in Michelet, Jules 1967, Histoire de France, La Révolution, vol. V. Lausanne: Ed. Rencontre, 292 (Barthes 1986a: 141).

3 With 'reality' and the 'real', I refer to Barthes's usage of these concepts in L'effet de réel. There they denote the lived world as something, which in the end defies any representation and meaning (see Barthes 1986a: 146).
} 
those where the body is presented as an erotic object of consumption. ${ }^{4}$ A gradual but clear development continues in his work: from a reader leaning on textual autonomy to a reader feeling affectively the movements of and within the body. Parallel to acting in the realm of the post-modern textual epistemology which tended to exclude signs of the lived body from semiotics, Barthes's early ideas of image as a mediated experience lay the basic concepts of social semiotics for the ideological critique of our everyday practices. Already then, when analysing the usage of non-linguistic signs in social situations such as fashion and commercial advertisements, he often points to the role of emotion in the signification process. This tendency increases towards the middle of the seventies, when Barthes openly begins to celebrate his affective, multiple, bodily experience in and of the world.

Finally, Barthes ends up with a systematic introspection of his own intrinsic reactions to photography in La chambre claire (1980). This was made possible through his experiences in Japan where he developed an enthusiasm for Zen Buddhist concepts and their scope of meaning beyond Western binary thinking systems. In my view, he later uses this orientation for an embodied seeing and reading of cultural objects in an experiential presence, which leaves behind Western theorisation without losing scientific precision. More precisely, as Barthes heads towards the pleasure of aesthetic plenitude felt in a historical body, he moves from the lost signified and textual alienation towards a reading in which emotion is recognised as a mode of processing knowledge in an intimate connection of cognition.

Drawing from this developmental trajectory, I will envision Barthes's progress towards the concept of a multisensory, affective body as the central historical site of an experiential human being, be it a writer, reader or viewer. In the light of his late writings comprised of the lectures held in the Collège de France in 1976-1979, and La chambre claire (1980), Barthes's concept of a textual ego pervaded by jouissance fuses with a Taoist, non-possessive, lived body in favour of a synaesthetic, euphoric vision of the world. This trajectory shows Barthes in search of a concept of subjectivity reminiscent of the theoretical idea of an embodied mind elaborated by cognitive psychology and social neuroscience from the beginning of the nineties

4 See, for example, 'Le Corps' in the essay Société, imagination, publicité (Barthes 1994/ 1995: 514-516; originally published in 1968). 


\section{Sirkka Knuuttila}

on. On this basis, my goal is finally to propose a renewed interpretation of his 'reality effect' in terms of our innate faculty of experiencing the world through sensory and perceptual routes in the presence of a seamless cooperation of emotion and cognition (Knuuttila [in press]). This process is included in the idea of a 'postrational' subjectivity, which is characterised by an innate, immediate ability to mirror other people's intentions and meanings. ${ }^{5}$ Seen in this frame, anticipating a theory of empathic reading/writing as a mode of witnessing the ongoing history of ordinary people, and not a history of experts and scholars, Barthes stands with those thinkers who partake in the long project of reformulating Cartesian rational subjectivity.

\section{The missing emotion of the reality effect}

One persistent thread in Barthes's writings is his many-sided commentary on the relationship between connotation and referentiality in literature and historiography. ${ }^{6}$ Committed to analyse all types of representations as a vehicle of political power, he systematically challenges automatic meanings elicited by verbal and visual discourses by uncovering the processes of mythologisation in the context of everyday life. ${ }^{7}$ Two of his central, though extreme positions deal with such processes. First, the ideological critique of the sixties

\footnotetext{
5 My term 'post-rational' originates from Vittorio F. Guidano, who emphasises that "while thinking usually changes thoughts, only feeling can change emotions" (Guidano 1991: 96). As he states, rationality is intrinsically relativistic, while the self-organising, self-referential system of every subject continuously reorders "immediate experiencing ("I") into a conscious sense of self and the world ("Me")" (Guidano 1991: 95-96). However, a "stable, and at the same time, dynamic demarcation between what is real and what is not in [a subject's] ongoing praxis of living" (Guidano 1991: 95), is enabled only through distinguishing perception from illusion verbally in a social interaction with other people (Toskala \& Hartikainen 2005: 27).

6 Barthes's early interest in an empty signifier which has no definite signified has its resonance in Roman Jakobson's 'zero signs' in linguistics as well as in Louis Hjelmslev's non-signifying sign elements, figurae (Chandler 2002: 74-75; Barthes 1994).

7 See Barthes's model of the mythologisation of sign in the chapter of "Myth today" in Mythologies (1994: 18); about its connection to Louis Hjelmslev's preceding model in his Prolegomena to a Theory of Language, see Silverman 1983: 26-27.
} 
attacks literary realism by claiming its signifier to be emptied of all content in prosaic representations. Second, the visual explorations of the seventies unveil the inability of canonised analytic studies of media to include the presence of the embodied aspects of life. Already in Le degré zéro de l'écriture (1953), Barthes juxtaposes the discourse of modernist poetry with classical realist texts, thereby foretelling his characterisation of the aesthetic mission of modernism as "challenging the age-old aesthetic of 'representation"' presented in L'effet de réel (Barthes 1986a: 148). Starting from an obvious conflict between verisimilitude and truth, he iteratively calls for counter-narratives ${ }^{8}$ which could put into effect the task of modernist aesthetics: the "disintegration of sign" (Barthes 1986a: 148). To shed light on his aspirations for alternative subtexts, I will concentrate on two of his articles considering the details of literary and cinematic mimesis: first, L'effet de réel (1968), and second, Le sens obtus (1970). Together these texts illuminate his semiotic account of the problems of referentiality in the verbal and visual image.

The outline of Barthes's progress in thinking about referential aspects of image is roughly as follows. ${ }^{9}$ First, after laying the basis for his concept of reality effect in 1966-1967, ${ }^{10}$ he gives in L'effet de réel a concise analysis of the process of emptying the signified in realistic representations in favour of his much debated "direct collusion of the signifier and referent" (Barthes 1986a: 147). He uncovers the naturalising discourse of the realistic novel and historiography as an ideologically marked chain of signifiers, which rather points to the absence of reality from realistic discourses than to the lived 'real' itself. In the mood of his post-modern contemporaries, he tries to resist the normative, controlling, political practice of texts similar to that of classical rhetoric in France. But while seeing human experiential truth as reduced to a decorative rhetoric, Barthes does not

8 For example, in Le troisième sens, Barthes understands the sens obtus to be an "epitome of a counter-narrative; disseminated, reversible, set to its own temporality" (Barthes 1982: 328).

9 For my description of Barthes's development at the turn of the decade I am indebted to Auli Viikari's insightful article Ancilla narrationis vai kutsumaton haltiatar? Kuvauksen poetiikkaa [Ancilla narrationis, or an uninvited fairy? Poetics of description] (Viikari 1993).

10 In the articles Introduction à l'analyse structural de récit (1966) and Le discourse de l'histoire (1967). 


\section{Sirkka Knuuttila}

reject the idea of textually produced pleasure and embodied presence. Quite the contrary, his neglect of the sensory and affective power of metaphor is temporary, even purposeful. Dazed by haiku poetry and the Zen Buddhist notion of satori after his Japanese journey, ${ }^{11}$ he soon turns to analyse his own ephemeral feelings elicited by Sergei Eisenstein's stills so as to transform them into the idea of sens obtus in Le troisième sens. While this move makes visible the emotional component of image through Eisenstein's theory of the vertical reading of the still, it lays the basis for the idea of punctum as an affective practice of seeing - feeling - a photograph. And while Barthes uses an introspective method he elaborated via an Eastern philosophical roundabout in order to avoid the terms of Husserlian phenomenology, the development of his ideas culminates in the practice of an embodied, affective reading of images with the mind's eye, textualised in La chambre claire.

In L'effet de réel, Barthes crystallises the problem of normative content in realism in the concept of an emptied signified. He finds it typical for all representative discourses, which try to mimic the truth of reality, including the efforts to enliven the 'real' world with photographs or exhibitions of authentic objects (Barthes 1986a: 146). Critical towards structuralism, he claims that the central devices transmitting a truthful world for a modern reader of realism are narratologically meaningless and non-functional descriptions and details of the everyday reality, termed the 'reality effect'. ${ }^{12}$ To illuminate the effect of this device in the long continuum of Western rhetoric as a contrast to medieval fantasy and classical eloquence, Barthes uses short passages that he understands as verbal efforts to create a feeling of verisimilitude. They are, for example, the scene of Corday in Michelet's historiography mentioned above, or the bour-

11 Originating from Barthes's visit to Japan, the parallelism of image and text presented in his L'Empire des signes (1970) is one example of an invisible interconnection of visual and verbal presentations meant to provoke a double signifying register of the unconscious and conscious activities in the reader's preconscious (see Silverman 1983: 72; Barthes 1994/1995: 745).

12 Barthes's distinction between classicism and modernism lies between Balzac and Flaubert (Barthes 1967: 32), while the 'real' world signifies for him the historical 'flesh world' we live in. And when he chooses Flaubert's text as an example of literary realism, he emphasises its historical simultaneity with the tradition of writing absolute History, which represents for him a rather short period of some decades in French historiography. 
geois setting in Flaubert's short story Un coeur simple where a barometer may play the role of a meaningless object. For my purpose, however, the most telling example of Barthes's critical position to realism is his approach to Flaubert's ekphrasis of Rouen in Emma Bovary. ${ }^{13}$ Making Rouen palpable by a few verbal substitutions of the historical place, the lyrical exactitude of this passage is for him one "jewel of a number of rarely brilliant metaphors" of the novel (Barthes 1986a: 144). It reads as follows:

[L]es mâts comme une forêt d'aiguilles, les îles comme de grands poissons noirs arrêtés, les nuages comme des flots aériens qui se brisent en silence contre une falaise [...] Ainsi, vu d'en haut, le paysage tout entier avait l'air immobile comme une peinture. (Barthes 1994/1995: 482)

[T] he masts like a forest of needles, the islands like huge motionless black fish, the clouds like aerial waves silently breaking against a cliff [...] Thus, seen from above, the whole landscape had the motionless look of a painting. (Barthes 1986a: 144-145)

According to Barthes' post-modern reading, the beauty of the three impressive similes of the passage is "subject to the tyrannical constraints of what we must call aesthetic verisimilitude" (Barthes 1986a: 145). When he prefers to read the image as a mimetic portrayal of the 'real' world, Flaubert's heavy, threatening scene hardly seems to point to the 'real' world in itself. Rather, being a verbal copy of a painting-like visual representation, the scene carries a functional chain of familiar connotations. It thus limits itself to a reduced signified whose sole denotative meaning is evoked by another, already thoughtout signifier, whereupon the whole scene attains a status of a mere "irrelevant" yet necessary excess in the construction of the artificial world. As a result, producing an absence of the signified of the 'real', the signifier of realism passes over all connotative signified by substituting them with one normative referent which tends to naturalise history (Barthes 1986a: 145).

Conspicuously, while refraining here from all explorations of how a mental representation of a past or fictional world is constituted in mind, Barthes puts aside the actual reader's perceptual and affective responses to the atmosphere of the image, which would characterise an act of creative reading. He discards deliberately the sensory charge

\footnotetext{
13 Ekphrasis refers here to "the verbal representation of visual representation" (on the historical usages of the term, see Mitchell 1994: 151-152).
} 
of the multitude of Flaubert's modernist signified in favour of his idea of an obscure collusion of the textual signifier and one normative referent. Thus the early Barthes seems to ignore the simultaneity of those direct and indirect figural devices which can "point to emotions and suffering without pointing at them", using Philippe Roger's words of Barthes's late writings (Roger 2001: 531). However, he fairly soon sketches out the analytical system of connotative codes in $S / Z$ (1973), and the interpretative exercise of still - a kind of visual parallel to Flaubert's ekphrasis - by Eisenstein's vertical reading in Le troisième sens (1973). But at the historical moment of 1968, Barthes commits himself to deconstruct the naturalising tendency of realistic discourse as an ideological gesture. His ambition is to uncover its pretended nature as a representation, which is to persuade, assure, and convince the reader of a predefined order in the world. As an outcome, the signified is conflated with the referent, while the signifier given is understood to evoke just one consistent, safe, and illusory world typical to the ideological goals of bourgeois realism and the history of scholars.

Nevertheless, as Michael Sheringham points out, what typifies Barthes's production from his early writings to the late is his aspiration to a third level of meaning formation that emerges by virtue of some unknown residues of signification which exceed the normative ones (Sheringham 2006: 194). Indeed, Barthes's cogent criticism of referential illusion proposes that whereas the signified of denotation is erased from the realistic speech-act; the "real' "returns to it as a signified of connotation" (Barthes 1986a: 148, italics added). This statement leaves the door open for the whole spectrum of a signified arising from an actual reader's personal flesh world and her/his specific cultural context. But while insisting on one signified as determined by the bourgeois context for canonised realist narratives, Barthes is not aware of the impact of post-modern ideology on himself which compels him to stick to an analysis of automatic denotations creating fallible feelings of 'reality'. He thus happens to ignore the indexical, affective and procedural, aspect of the interpretant elicited by any discourse in the reader's individual body. ${ }^{14}$ Therefore,

14 In my view, taking into account the embodied, historical indexicality of the interpretant, we can specify how discourses act as referential bridges from text to world in semiosis, an idea proposed by Mikhail Bakhtin, Paul Ricoeur, and Edward Said. Indeed, as Eelco Runia succinctly notes, Barthes's theory points to 
Barthes's critique of realistic discourse cannot yet be suggestive of a theory of representation which recognises emotion as a (missing) component of cognition in the long venture of rectifying the Cartesian rational concept of subjectivity. The result is that, while neglecting the sensing, affective body as a source of knowing by his somewhat mystical collusion of signifier and referent, Barthes's interpretation seems to perpetuate the Cartesian idea of a bodiless mind at this stage of his intellectual progress.

\section{Towards a lived body in presence: The poetics of still}

Today, as the relationship of emotion and cognition in human intellectual activity is under a profound re-evaluation, it is possible to see more clearly the limited role of emotion in Barthes's early writings. From the beginning of the nineties, a revised concept of an embodied subjectivity is gradually formulated by cognitive psychology, especially in its line of radical constructivism, assisted and supported by the remarkable empirical evidence of contemporary neuroscience. ${ }^{15}$

the possibility of presence in the absence of history/reality as a "stowaway" through common metonymies, which act as "temporal fistulae" between past and presence (Runia 2006: 1, 16). This idea is akin to Barthes's own statement that vraisemblance is expressed merely through common opinion (Barthes 1986a: 147). However, Runia does not consider our innate faculty to respond to perceptual material affectively as an embodied mirroring in the production of mental representations of other people and the world, nor does he discuss the evidence that such mirroring is evoked also by linguistic expressions (see Keen 2006: 209).

15 The renewed concept of subjectivity is effectively formulated by the cognitive theorist Vittorio Guidano, who in his work Self in Process (1991) lays a fruitful basis for a concept of a processual self developing in a mutual affective and embodied connection with the m/other. The roots for Guidano's and Gianni Liotti's theoretical approach of radical constructivism, developed in the Psychiatric Clinic of the University of Rome, are based on the ideas of Francisco Varela and Humberto Maturana originating from the seventies, while the theory of emotion is reformulated by Joseph LeDoux and, especially, Antonio Damasio and numerous other cognitive neuroscientists in the nineties. Moreover, despite doubts concerning the relevance of neuroscience to psychoanalytical practice, an active international debate continues on the position and nature of Freudian psychoanalysis in this developing configuration, while a theoretical line called 


\section{Sirkka Knuuttila}

The concept of a feeling, post-rational, subjectivity allows for the seamless cooperation of emotion and cognition as a foundation for human intellectual activity and social capacity (Damasio 2003; LeDoux 1996). Currently, emotion is understood as ubiquitous and dialogical in all cognitive activity in the regulation of our choices and reasoning. What is more, it is the basis of our social capability, for it partakes in our innate mirroring of the other person's intentions and feelings through a continuous registration of the flow of non-verbal signs (Rizzolatti et al. 2001; Gallese 2005; Iacoboni 2005; Keen 2006). ${ }^{16}$ Furthermore, the theory of an embodied subjectivity supposes that a wordless, visuo-spatial and procedural - multisensory, visceral, and proprioseptic - knowing is on an upper level in the functional structure of human consciousness in relation to language (Toskala 2006; Guidano 1991; Damasio 2000). For literary and media studies this implies, for instance, that the affective and dynamic visuospatial component of metaphor has to be taken along as an integral part of information processing when reading cultural representations, whereupon a place for an embodied historical reader is prepared (Knuuttila [in press]; Miall 2006). On this ground, to introduce a consistent theory of reading, one has to postulate an embodied, affective historical reader, and embrace the role of the indexical aspect of the sign as a component of reading response.

In this theoretical frame, I follow how the sense of a feeling body increases in Barthes's theorising on image towards the end of the seventies. The embodied response he reports to have in face of visual material evokes the idea of an indexical referentiality residing in an affective perception of filmic and photographic images. An impressive prologue to this phase is a passage in Le degré zéro de l'écriture, where Barthes indicates his enthusiasm for the violent autonomy of modernist poetry (Barthes 1967: 35-43). In contrast to the controlling economics of classical realism, he experiences the verbal imagery of new poetry (since Rimbaud, not including Baudelaire) to be endlessly

neuropsychoanalysis points to some important ideas relevant for a renewed concept of transference.

16 The neural correlate of mirroring the other person's intentions, feelings, and motivations seems to be a complex mirror neuron system, which, however, can never be equated with the system of psychological functioning, while the incompatibility and incommensurability of these two disparate representative systems is doomed to remain eternal (see Damasio 2000: 83). 
liberating due to the explosive power of its multiple signified. As if anticipating the idea of obtus, Barthes views the intellectual and emotional condensation of modernist poetry to give birth to a vertical discourse (Barthes 1967: 40), ${ }^{17}$ which opens the way for an unexpected but ripened thought in and through a co-presence of arbitrary words.

However, although it marks a revelation of truth for Barthes which he expresses in one of his most beautiful passages, he feels that modernist poetry excludes the reader by changing Nature into isolated, frightening objects without continuity. Reading modernist poetry seems for him to plunge one terrified into an existential thrownness in an estranged world, and leave one detached from social connections with other people (Barthes 1967: 42). ${ }^{18}$ This experience leads Barthes - a future master of poetic fragments - to characterise modernist poetry as an unhistorical and unethical "climate" arisen from the fragmentary qualities of a discourse where there is "no humanism" (Barthes 1967: 42-43). But what is more important, his own existential curiosity propels him towards the idea of an ephemeral third meaning, the obtus. This quest compels him to ask the most relevant questions concerning the anti-Cartesian reformulation of a feeling subjectivity.

It is surprising how clearly the absence of emotion from the theory of mind can be seen in Barthes's search for the essence of the obtuse meaning when reading an image. In terms of his triple division of meaning presented in Le troisième sens, Barthes was not interested in the first mode, information transmitted in communication. Rather, he wanted to scrutinise the fundamental nature of the second, symbolic signification in relation to the third, the obtuse meaning. In contrast to the obvious, the obtuse meaning corresponds in the first place to Julia Kristeva's term signifiance as a bodily process, which has more to do with the signifier than the signified (Barthes 1982: 319). Being convinced that there exists a kind of excess of visual content in Eisen-

\footnotetext{
17 He writes: "Fixed connections being abolished, the word is left only with a vertical project, it is like a monolith, or a pillar which plunges into a totality of meanings, reflexes, and recollections" (Barthes 1967: 40).

18 More precisely, while Nature becomes a "succession of verticalities", and "objects filled with all their possibilities", the reader is left alone with "inhuman images of heaven, hell, holiness, childhood, madness, and pure matter" (Barthes 1967: 42).
} 


\section{Sirkka Knuuttila}

stein's stills, Barthes observed that the signified of this "evident, erratic, obstinate" meaning was extremely hard to explicate. He writes: "I do not know what its signified is, at least I am unable to give it a name, but I can see clearly the traits, the signifying accidents of which this - consequently incomplete - sign is composed: a certain compactness [...]" (Barthes 1982: 318).

Today this eloquent textual groping evokes a certain kind of embarrassment, for it seems to indicate symptomatically our huge ignorance of the role of emotion in intellectual thinking throughout modernism. Strikingly similar to Barthes's insignificant reality effect and the unknown obtus, emotion has been taken for an excess while still being the necessary opposite to reason in the Western concept of subjectivity in its long Cartesian history. This gap makes Barthes's endeavour to identify the signified of the obtuse meaning still more valuable, even when he draws on euphemisms in describing the essence of this 'something' whose unknown existence he never seems to doubt, and which seems to imply a wordless, emotional mode of cognition occurring on the core level of the subject (see Damasio 2000: 169, 174).

Barthes specifies the impact of stills on himself by itemising his felt responses to a selected cavalcade of images of Eisenstein's Ivan the Terrible. The third meaning is an emotional, evaluative process where the reader is dismantled by the sign - the same procedure completed with the punctum in relation to photographs in La chambre claire. But how does this disarming take place? In a way, the problem of obtus echoes the question in Rhetoric de l'image (1964) of what remains in the image when all connotative messages of the iconic sign are deleted, but when its literal denotation remains uncertain and without a symbolic code (Barthes 1977a: 36, 42-43). ${ }^{19}$ In the form of obtus, this uncertainty is defined as a "spasm of the signified" which is not empty; rather, it accentuates some transition point of desire emerging on the boundary of before and past (Barthes 1982: 327). But importantly, Barthes argues that obtus is not the gestural or facial expression of an emotion, which belongs to the realm of obvious meaning of a realist, decorative image (Barthes 1982: 322).

\footnotetext{
19 Already in 1964, Barthes speaks about the temporal double structure of the photograph: being-there and having-been-there, whose repercussions one can hear, again, in La chambre claire (see Barthes 1977a: 44).
} 
This limit draws my attention to the most telling example illuminating the incipient transition typical to obtus: the still of an old Russian woman just before emitting an open cry of grief. I am prone to interpret this fleeting moment as that of the non-cognitive appraisal occurring in the body at the kindling point of a strong affect. Here this ephemeral moment of an emerging emotional feeling begins with an impediment of breathing when a person is not yet aware of the intrusive change of her/his bodily condition, but which can be recognised non-verbally by another sensitive person. ${ }^{20}$ An apposite theoretical tool for grasping such an embodied psychological change is the concept of 'felt emotion' as defined by Don Kuiken. In accordance to 'felt emotion', obtus supposes the "experience of inner tensions related to the response-organising activities of the basic emotions, such as fear, anger, and sadness" (Kuiken 1995: 142). Furthermore, obtus may essentially be related to the psychic phenomenon of 'felt engagement', defined as an 'experience of inner tensions related to positions and actions taken vis-à-vis the environment" (Kuiken 1995: 142). ${ }^{21}$

Drawing on these psychological premises, I define obtus as a feeling of wordless, embodied cognition that emerges during the transition from one emotional condition to another, supposing that this transition can come into consciousness only when not verbalised, as Daniel N. Stern observes. However, as he notes, only an awareness of such a felt experience provides the material for a possible verbal

20 The fleeting moment at the beginning of an emotional wave is termed the noncognitive appraisal in the judgment theory of emotion (see Robinson 2005: 41-42; Knuuttila [in press]). Yet, to speak about 'beginning' of an emotional feeling implies that the emotional process is understood to be a continual phenomenon where the lower and higher waves of embodied feelings tend to emerge in turn so as to form a temporal contour of vitality affects (Stern 2004: 64).

21 Behind both these concepts is Rudolf Arnheim's aesthetic notion of 'felt presence' of an image, which implies that outer objects themselves have perceptible tensions that have a direct effect on the experience of the spectator (Kuiken 1995: 142-143). I propose that 'felt presence' could be a pertinent device to deal with Barthes's obtuse emotional reacting to the visual details of Eisenstein's stills, such as the "tenuous relationships between the contrasting curves of the woman's low headscarf, her closed eyes, and convex mouth" (Barthes 1982: 322). And when the visual object represents a human being, felt presence belongs to the realm of mirroring the other, which makes the whole issue more complex. 
recounting (Stern 2004: 32). This approach explains Barthes's intention to stop at one certain still where the uncertainty of the affect is at its height, and reveals the beginning of a violent emotional process in one bodily flash which normally is beyond conscious perception. But because the obtuse meaning "does not copy anything" like the obvious one, to describe the emotion value it carries is impossible (Barthes 1982: 326). But tellingly, Barthes finds a suitable verbal articulation for his experience of obtus in the haiku (Barthes 1982: 327). ${ }^{22}$ This might be the same experience of embodied knowing that makes Barthes write later: "I can neither read nor write what you produce, but I receive it, like a fire, a drug, an enigmatic disorganization" (Barthes 1977c: 118; his italics).

Barthes's elaboration of a new method of deciphering image through the third meaning is based on the idea of vertical reading which Eisenstein adapted in his still frames. According to Eisenstein, being a passage from language to significance, obtus is a counternarrative which, with its "accentuation within the fragment" — "the element "inside the shot", _ "creates another film" by "structuring it differently [from within] without subverting the story" (Barthes 1982: 332; his italics). Most importantly to literary interpretation, this idea suggests a reading practice that is based on an undulation of wordless, directly felt, embodied micro-narratives occurring as emotional transitions at the core level of a sensing subject (see Stern 2004: 58). Such a practice is put into effect in Barthes's own version of vertical reading ten years later, which marks his first step toward a systematic usage of introspection as a method of exploring affects elicited by photographic details.

Vertical reading could also have relevance as a method in the interpretation of literary ekphrasis, which is comprised of a palimpsest of affective metaphors, such as Flaubert's verbal image of Rouen quoted above. This idea gets a good sounding board in Barthes's reading of stills which in a way responds to his request for a theory of reading in the seventies. Already La mort de l'auteur (1968), longs for a theory of reading with its concept of a reader as an intertextual space

22 Barthes cannot explicate the effect of the woman's figure, except by the simile "like a fish out of water" (Barthes 1982: 322). However, he finds a more subtle expression in the haiku by which he manages to bring about the co-presence of visual details to create the emotional meaning in the experiencing reader: "Mouth drawn / Eyes shut squinting / Headscarf low over forehead / She weeps" (Barthes 1982: 326). 
where all multiple aspects of the text meet in the experience of reading. Going further, Le Plaisir du texte (1973) begins to express Barthes's own responses to texts he desired to read along with his personal predilections and affections. In Sur la lecture (1976), he states at first: "Unfortunately, reading has not yet encountered its Propp or its Saussure" (Barthes 1986b: 34). Then, specifying his earlier demand concerning "the birth of the reader must be at the cost of the death of the Author" (Barthes 1977b: 148), he describes the bodily disorder of a feeling, desiring reader. With the benefit of hindsight, I see these undertakings as calling for a theory of reading where emotion has a recognised function in processing knowledge not only as a catalyst, but also as a dimension of non-verbal, embodied cognition (Knuuttila [in press]). ${ }^{23}$

\section{Affective introspection as a method: punctum}

A flesh world begins to show up more clearly in Barthes's orientation toward the indexicality of the feeling body in Le Plaisir du texte, where he formulates his concept of the mundane subject as an enjoying entity full of erotic pleasure. With his dialectical style by alternating 'I' and 'he' in Barthes par Barthes, he incarnates the internal division of a dialogical, plural body, whose dialectics he exemplifies by echoing some earlier discussion: "Which body? We have several" (Barthes 1977c: 60). Oscillating between suffering and pleasure, his body is "especially: emotive: which is moved, stirred, depressed, or exalted or intimidated, without anything of the sort being apparent" (Barthes 1977c: 60-61, his italics). Being aware of his own panic provoked by the language used in domestic quarrels in his childhood (Barthes 1977c: 159), ${ }^{24}$ he continues to underline the

\footnotetext{
23 In empirical literary research, the episodic simulation of a textual passage is called 'expressive enactment', where a felt emotion and felt engagement of the reader work together with the felt presence of the object, and produce in the reader an emotional shift between bodily enacted episodes. This reaction is individual and depends on the autobiographical experiences of the reader (Kuiken et al. 2004: 269, 281-284; on emotion in metaphor and reading, see also Miall 2006, passim).

24 In this connection, Barthes comes up with a paradoxical maxim: "[A] cessation of language is the greatest violence that can be done to the violence of language" (Barthes 1977c: 159).
} 


\section{Sirkka Knuuttila}

role of language in creating subjectivity. In the fragment of "Nouvelle sujet, nouvelle science", he claims: "He [Barthes] wants to side with any writing whose principle is that the subject is merely an effect of language. He imagines an enormous science, in the utterance of which the scientist would at last include himself - the science of the effects of language" (Barthes 1977c: 79, his italics). Is this daydream of drowning himself in scientific language ironic? Anyhow, to counteract the scientific "madness of language", he complains that we Western researchers - throw a shadow of suspicion on every utterance by revealing their graded meta-levels, whereby we call this abyss of language as an act of utterance. He notes: "I write: this is the first degree of language. Then, I write that $I$ write; this is the second degree of language" (Barthes 1977c: 66, his italics).

Barthes's weariness with meaningless theorising and his active search for the immediacy of presence is finally concretised in the lectures of Collège de France. He begins to explore certain Eastern concepts as substitutes for a number of Western ones that cannot easily mediate the subtle qualities of his craved, "antirelevant" experiences of Zen (Barthes 2005: 117). I find this turn a necessary pathway to the introspective method of image whose indispensable results are seen in the verbal jewels of La chambre claire. In Le Neutral (1977-1978), Barthes prepares himself this pathway towards a new research technique by exploring two key notions: Greek kairos and Chinese wou-wei (Barthes 2005: 169-171). Only then was he ready to adopt introspection as a systematic method of analysing his own affective reactions to photographs in a contemplative awareness of his own body. Emphasising the Taoist wou-wei as an attitude of non-involvement, he completes it with the kairos of the philosophical Sceptics of the ancient Greek Academy to underline the non-dogmatic nature of an "a-power" of wou-wei (Barthes 2005: 170). ${ }^{25}$ From these elements, he develops a variation of Husserlian phenomenological

\footnotetext{
25 Ho kairos refers to a right, appropriate measure, an appropriate, timely moment or opportunity. It points to the right, relaxed moment of an occasion (Barthes 2005: 169). Wou-wei implies non-action which guides one not to direct one's strength, but rather to "suspend his judgment in cases where it is a question of arriving at the truth". Its deepest attitude is "not to choose" (Barthes 2005: 176). Together, these two form an Eastern analogue to Husserl's introspection, where unconscious or subconscious experiences may unfold into consciousness (see, e.g., Vermersch 1999).
} 
reduction, however, with the difference that he substitutes its term epochè - the gesture of suspension - with the non-action of wouwei combined with kairos - the right moment (of acting).

In this frame, Barthes's last period can hardly be characterised as a time of laziness (Saint-Amand 2001); by contrast, he purposefully propagates an active non-action as an alternative to the capitalist, commercialised, and hectic routines of Western life. Similar to Husserlian epochè, but seldom using this term (see Barthes 2005: 118), Barthes uses wou-wei to imply an abstinence from all judgments in order to find a lived, experiential presence in the corporeal awareness of (his) personal existence. Thus, instead of dealing with the abstract Husserlian transcendental ego, Barthes promulgates a contextual and temporal bodily presence in flesh. And when turning inwards, he does not forget an outward movement which guides him implicitly toward a renewed concept of indexical referentiality of perceived objects transmitted through a sensing and feeling body (see Knuuttila 2007: 40-46, 49).

Eventually, during his mother's terminal period of life, Barthes touches the unresolved nature of human procedural and emotional memory by exploring his bodily feelings evoked by photographs. The detailed self-reflexive response to these feelings presented in $L a$ chambre claire completes his lengthy philosophical predilection for visual historical objects. In the light of his last lectures, La chambre claire can be identified as a result of an introspective epochè: a standstill with photos in deliberate submission to the affective power of punctum: "desire, repulsion, nostalgia, euphoria" (Barthes 1981: $21)$. When verbalising his mental movements, Barthes reads photographs as if exemplifying the method of an empathic reading. Yielding himself to the image, he lets the visual sign dismantle himself through the 'expressive enactment' of a multitude of sensations and affects (Kuiken et al. 2004: 269, 281-284; see note 23). He writes it down poetically, thanks to the free acceptance enabled by the Zen Buddhist state of satori (Barthes 1994/1995: 745). But still more fruitful is the distance he takes from the Western phenomenological reduction, which tends to decontextualise the subject. Assuming a position of wou-wei, as he surrenders to the insecure awareness of all his affects and thoughts, Barthes relates them to his culture in studium by going through all those subconscious details of his autobiographical existence that are elicited by the procedural, perceptual, and 
visceral memory of punctum. Hence, the intentional object of Barthes's introspection is twofold: when attempting to become conscious of his unconscious material, he also wants to be aware of the act of introspection itself. In other words, as he observes the structure of emerging affect with all its multisensory and perceptual components, he simultaneously explores the spontaneous verbalisation of these emerging components.

As a result, the Barthesian combination of two signifying practices of studium and punctum shows the subject as a continuous process between preconscious and conscious: the embodied, implicit memory and the symbolic, explicit memory. ${ }^{26}$ According to the radical constructivism of embodied subjectivity, non-verbal, multi-sensory cognition precedes our verbal constructions of the world, while emotion ubiquitously pervades the cognitive activity of a socially competent, empathic subject. I interpret the late Barthes to exemplify this capability on the core level of subjectivity. Following logically from this idea, his method of introspection and its verbalisation as a viewer of historical documents indicates his strong protest against a monological, possessive Western mind in favour of a subjectivity which is continually reconstructed in human relationships and cultural contexts. This method is most fruitful in Barthes's finding that the noema of the photo is the temporal double structure "this will be" and 'this has been', which fuses into an existential experience of the viewer's own mortality (Barthes 1981: 96). The duality of this noema is profoundly historical to Barthes who wants the temporal paradox to continue in effect through touching figures. And being visual and verbal images of historical individuals, such affective figures may remain in force by exciting our bodily memory by virtue of their interactional, indexical power.

26 A detailed analysis of this procedure is presented in Knuuttila 2007. The tension between studium and punctum is similar to the tension which prevails between the experiential ' $\mathrm{I}$ ' and self-reflexive 'Me' in Guidano's cognitive terms, and to the Freudian fundamental dynamic tension between enactment and representation. A functional bridge between these two poles, as Kaja Silverman proposes, could be the early Freudian preconscious which is the potential source of our figural talent, for it mediates between unconscious and conscious in the double-signifying register of thing-presentations and word-presentations (Silverman 1983: 72, 86). 


\section{Conclusion: $L$ 'effet de réel revisited}

To sum up, in light of La chambre claire, I will reinterpret Barthes's example of Charlotte Corday compared with that of Lewis Payne, who are in the same position as they are committed to death and will soon be executed due to their political actions. As presented in this essay, Barthes's later writings offer a model of multisensory affectivity in reading images with an awareness of one's own bodily and emotional reactions. This model prompts me to suggest a renewed notion of an embodied reality effect when reading verbal portrayals of persons and milieus. Earlier, as Barthes questions the meaning of "insignificant" textual details in L'effet de réel, he claims their ekphrastic role in the creation of a truthful sense of the lived world to be conventional and naturalising in the realistic novel and historiography in the sense of mere "luxury" or excess (Barthes 1986a: 141). He then passes over, in terms of lost signified, the immersing signifiance of the visuo-spatial and affective details of the setting for a philosophical interpretation of the image, such as Corday's posture between the painter and the small door through which Corday is soon going to be executed. However, twelve years later, when mindfully regarding Lewis Payne's photograph taken by Alexander Gardner in 1865 in a similar situation in prison, Barthes feels affectively the double temporal structure of a historical document: the simultaneity of "this will be" and "this has been", but reversed into an existentially touching combination of "Il est mort et il va mourir" (Barthes 1994/1995: 1177). Extrapolating from the parallelism of these two images, I show the significance of an embodied reading to Michelet's concise - one sentence long in Barthes 1968 - but visuo-spatially and affectively effective ekphrasis of the historical figure of Corday.

As Michelet indicates, just as Payne for the photographer, Corday poses for a painter who is completing her last portrait before her legallyplanned execution - a sign of man-made trauma. Similar to Payne's posture and direct gaze at the photographer, the text on Corday evokes at one verbal swoop a mental image where the prisoner is supposedly looking at the painter when sitting in the front of the small door that leads to her only possible destiny: death. This scene is doubly compelling to the reader in terms of the sensory and affective perspective of a post-rational subject. According to the theory of wordless cognition and mirror neuron functioning, the viewed as well as the narrated gestures and qualities of 


\section{Sirkka Knuuttila}

the object activate the recipient's body, which exhibits the feelings and intentions of that object in an inner drama of their embodied simulation. ${ }^{27}$ But this act is fundamentally dialogical, for when the reader adopts unconsciously the position of the painter or the photographer, s/he also identifies her/himself with the role of the posing prisoner through her/his mind's kinaesthetic and affective, multisensory eye - a "second sight" (Barthes 1981: 47). Being the route to the reader's individual embodied memory, such a response implies unavoidably the creation of "another (emotional) film" of the scene in the body: an embodied simulation of the wordless dialogue emerging from the dramatic tension between both accomplices of the still as based on their mutual 'felt engagement'.

Furthermore, as Barthes mentions, the careful knocking on the prison's small door enhances the reader's dramatic sense of reality. But besides announcing the moment of death, the knocking increases the reader's emotional confusion in her/his imagined place of a third person - a witness - as $\mathrm{s} / \mathrm{he}$ is oscillating between the opposite roles of the painter and the prisoner. The result is a persistent ambiguity: while the spatial and objectifying identification with the painter offers the reader an important role as an observer in relation to Corday who is soon to be executed, the identification with Corday tends to immerse the reader in the obtuse 'felt emotion' of her/his own definitive death. ${ }^{28}$ The compelling outcome from this embodied reality effect is that the reader is to bear testimony of historical atrocities from an ethically evaluative position of a living, yet mortal historical person.

In conclusion, Barthes's emphasis on experiential truth in reading these items of cultural media can be seen as a foreshadowing of a theory of empathic reading and the coming formation of the concept of emotionally knowing subjectivity. Regarding his examples, since death through a planned execution is posed in the absolute past in the visual example of Payne, Barthes finds his experiential self in the fear of a historical "catastrophe which has already occurred" (Barthes 1981: 96). ${ }^{29}$ The trembling textual Barthes then manages to shift the

\footnotetext{
27 See Keen 2006: 209, 225 n3.

28 As presented earlier in this essay, 'felt emotion' refers to an "experience of inner tensions related to the response-organising activities of the basic emotions, such as fear, anger, and sadness" (Kuiken 1995: 142).

29 This experience points to an adaptive psychic process where the dissociated emotional part of the personality is integrated with the apparently normal part of the personality in the act of embodied viewing/ writing/ reading (cf. Howell 2005:
} 
feeling of the double temporality of "this has been" and "this will be" into the flesh of the viewer in La chambre claire. Likewise, the realistic portrayal of Corday as a potentially dead person is not merely to produce a sense of referential illusion by saying "I am reality" in a frame of one dominant and unique emplotment (Jay 2001: 473, 475). Instead of one temporal signified - that of the imminent arrival of death/executioner - for an embodied recipient of a documentary, a multitude of signified may open up in the experiential truth of her/his own corporeality through the awareness of the living body at the moment of reading. Finally, this is indicative of the return of a multiple, multisensory, though disquieting, signified to a realistic representation, traced originally by Barthes himself.

\section{References}

Barthes, Roland 1967. Writing Degree Zero \& Elements of Semiology. London: Jonathan Cape Ltd. [Trans. Annette Lavers and Colin Smith.]

- 1974. S/Z. Oxford, New York: Blackwell. [Trans. Richard Miller.]

- 1975. The Pleasure of the Text. New York: Basil Blackwell. [Trans. Richard Miller.]

- 1977a. Rhetoric of the image. In: Roland Barthes: Image - Music - Text. Essays. London: Fontana Press, 32-51. [Trans. Stephen Heath.]

- 1977b. The death of the author. In: Roland Barthes: Image - Music - Text. Essays. London: Fontana Press, 142-148. [Trans. Stephen Heath.]

- 1977c. Roland Barthes by Roland Barthes. Berkeley, Los Angeles: University of California Press. [Trans. Richard Howard.]

- 1981. Camera Lucida. Reflections on Photography. New York: Hill and Wang. [Trans. Richard Howard.]

- 1982. The third meaning. In: Sontag, Susan (ed.), A Barthes Reader. New York: Hill and Wang, 317-333.

- 1986a. The reality effect. In: The Rustle of Language. New York: Basil Blackwell, 141-148. [Trans. Richard Howard.]

- 1986b. On reading. In: The Rustle of Language. New York: Basil Blackwell, 33-43. [Trans. Richard Howard.]

- 1994. Myth today. In: Easthope, Antony; McGowan, Kate (eds.), A Critical and Cultural Theory Reader. Buckingham: Open University Press, 14-20.

- 1994/1995. Euvres complètes. Tome I et II. Paris: Éditions du Seuil.

- 2003. La préparation du roman I et II. Cours et séminaires au Collège de France (1978-1979 et 1979-1980). Paris: Editions du Seuil.

132-133). For me, such an integration indicates the way in which one's sense of metonymical (indexical) contiguity may recover from numbness. 


\section{Sirkka Knuuttila}

- 2005. The Neutral. Lecture Course at the Collège de France (1977-1978). New York: Columbia University Press. [Trans. Rosalind E. Krauss and Denis Hollier.]

Chandler, Daniel 2002. Semiotics: The Basics. London: Routledge.

Damasio, Antonio 2000. The Feeling of What Happens. Body, Emotion, and the Making of Consciousness. London: Vintage.

- 2003. Feeling of emotion and the self. Annals of the New York Academy of Sciences 1001: 253-261.

Depraz, Natalie 1999. The phenomenological reduction as praxis. In: Varela Francisco J.; Shear, Jonathan (eds.), The View from Within: First-Person Approaches to the Study of Consciousness. Journal of Consciousness Studies 6(2-3): 95-110.

Gallese, Vittorio 2005. 'Being Like Me': Self-Other Identity, Mirror Neurons, and Empathy. In: Hurley, Susan; Chater; Nick (eds.), Perspectives on Imitation: From Cognitive Neuroscience to Social Science, vol. 1. Cambridge: MIT Press, 101-118.

Guidano, Vittorio F. 1991. The Self in Process. Toward a Post-Rationalist Cognitive Therapy. New York and London: The Guilford Press.

Howell, Elizabeth F. 2005. The Dissociative Mind. London: The Analytic Press.

Iacoboni, Marco 2005. Understanding others: Imitation, language, empathy. In: Hurley, Susan; Chater, Nick (eds.), Perspectives on Imitation: From Cognitive Neuroscience to Social Science, vol. 1. Cambridge: MIT Press, 77-100.

Jay, Martin 2001. Roland Barthes and the tricks of experience. The Yale Journal of Criticism 14(2): 469-476.

Keen, Suzanne 2006. A theory of narrative empathy. Narrative 14(3): 207-236.

Knuuttila, Sirkka. 2007. Barthes ja punctumin peitetty mieli. [Barthes and the covered sense of punctum] In: Harri Veivo (ed.), Vastarinta / resistanssi, Helsinki: Yliopistopaino, 33-53.

- [in press]. Bodily dialogues. Indexicality of emotion in literary experience. In: Veivo, Harri; Ljungberg, Christina; Johansen, Jørgen Dines (eds.), Literary Semiotics Now. Cambridge: Cambridge Scholars Press.

Kuiken, Don 1995. Dreams and feeling realization. Dreaming 5(3): 129-157.

Kuiken, Don; Phillips, Leah; Gregus, Michelle; Miall, David S.; Verbitsky, Mark; Tonkonogy, Anna 2004. Locating self-modifying feelings within literary reading. Discourse Processes 38(2): 267-286.

LeDoux, Joseph. 1996. The Emotional Brain: The Mysterious Underpinnings of Emotional Life. New York: Simon \& Schuster.

Miall, David S. 2006. Literary Reading: Empirical \& Theoretical Studies. New York: Peter Lang Publishing.

Mitchell, William J. T. 1994. Picture Theory: Essays on Verbal and Visual Representation. Chicago and London: The University of Chicago Press.

Perrone-Moïses, Leyla 2001. Leçon: Testament and prophecy. The Yale Journal of Criticism 14(2): 463-468.

Rizzolatti, Giacomo; Fogassi, Leonardo; Gallese, Vittorio 2001. Neurophysiological mechanisms underlying the understanding and imitation of action. Nature Reviews Neuroscience 2(9): 661-670. 
Robinson, Jenefer 2005. Deeper Than Reason. Emotion and its Role in Literature, Music, and Art. Oxford: Clarendon Press.

Roger, Philippe 2001. Caritas incarnate: A tale of love and loss. The Yale Journal of Criticism 14(2): 527-533.

Runia, Eelco 2006. Presence. History and Theory 45(February): 1-29.

Saint-Amand, Pierre 2001. Barthes's laziness. The Yale Journal of Criticism 14(2): 519-526.

Sheringham, Michael 2006. Everyday Life. Theories and Practices from Surrealism to the Present. Oxford, New York: Oxford University Press.

Silverman, Kaja 1983. The Subject of Semiotics. New York: Oxford University Press.

Stern, Daniel 2004. The Present Moment in Psychotherapy and Everyday Life. New York and London: W. W. Norton \& Company Ltd.

Toskala, Antero; Hartikainen, Katja 2005. Minuuden rakentuminen. Psyykkinen kehitys ja kognitiivinen psykoterapia. Jyväskylän Koulutuskeskus Oy, Jyväskylä: Otavan Kirjapaino.

Varela, Francisco J.; Thompson, Evan; Rosch, Eleanor 1993. The Embodied Mind: Cognitive Science and Human Experience. Cambridge: The MIT Press.

Vermersch, Pierre 1999. Introspection as practice. In: Varela Francisco J.; Shear, Jonathan (eds.), The View from Within: First-Person Approaches to the Study of Consciousness. Journal of Consciousness Studies 6(2/3): 17-42.

Viikari, Auli 1993. Ancilla narrationis vai kutsumaton haltiatar? Kuvauksen poetiikkaa. In: Ahokas, Pirjo; Rojola, Lea (eds.), Toiseuden politiikat. Kirjallisuudentutkijain Seuran vuosikirja 47/1993. Helsinki: Suomalaisen Kirjallisuuden seura, 60-84.

\section{Еще раз об «эффекте реальности»: Барт и аффективное изображение}

Настоящая статья посвящена развитию Ролана Барта из структуралистского семиотика в чутко реагирующего (сверхчувствительного) читателя в смысле «пост-рациональной» субъективности. Рассматривая творчество Барта как одно целое, можно его считать предшественником современной когнитивной науки, так как Барт считает эмоцию неразрывной частью познания. Чтобы показать, как осознанность Барта этого эпистемологического изменения постепенно углублялась, данная статья начинает свой анализ с бартовского понятия «эффекта реальности», который является основным носителем реалистической репрезентации. Далее Барт обращает свое внимание на образование понятия аффективного чтения, которое противостоит общепринятому пониманию об одном, идеологически заранее определенном обозначаемом. Дорогу Барта к пониманию чувств реального читателя поддерживают две идеи: «бесчувственность» 


\section{Sirkka Knuuttila}

значения кинокадров и опыт punctuma в фотографии. В лекциях, прочитанных в Коллеж де Франс, можно наблюдать, как Барт заменяет в своей читательской практике гуссерлевский метод бестелесного внутренного наблюдения китайским методом wu-wei. Благодаря этому из бартовского дзенбуддистского интереса к чувствам, вызванным визуальными/вербальными образами, вырастает отдельный метод, который может создать плодотворную связь между языком и внеязыковой перцепцией. В конце статьи предлагается понятие «бестелесного эффекта реальности», поддерживаемое примером аффективного чтения двух похожих сцен, которые сам Барт истолковывал в ранней и поздней стадии своей карьеры.

\section{Taaskord 'reaalsusefektist': Barthes ja afektiivne kujund}

Käesolev artikkel on pühendatud Barthes'i arengule strukturalistlikust semiootikust tundeliseks lugejaks 'post-ratsionaalse' subjektiivsuse mõistes. Vaadates Barthes'i loomingut tervikuna, võib teda pidada moodsa sotsiaalse neuroteaduse eelkäijaks, kuivõrd Barthes peab emotsiooni tunnetuse lahutamatuks osaks. Illustreerimaks, kuidas Barthes'i teadlikkus sellest epistemoloogilisest muutusest järjest süvenes, alustab käesolev artikkel analüüsi tema tekstianalüütilisest mõistest 'reaalsusefekt', mis on realistliku esitusviisi põhiliseks kandjaks. Edasi pöörab Barthes oma tähelepanu afektiivse lugemise mõiste kujundamisele, mis astub vastu valitsevaks muutuvale arusaamale ühest ja ainulisest ideoloogiliselt määratud tähistatavast. Barthes'i teed reaalses lugejas kehastunud tunnete mõistmise poole sillutavad kaks ideed: filmikaadrite tähenduse tuimus ja punctum'i kogemus fotograafias. Collège de France'is peetud loengutes võib näha, kuidas Barthes asendab lugemispraktikas husserlliku kehatu sisevaatluse meetodi hiina $w u$-wei meetodiga. Tänu sellele saab Barthes'i zen-budistlikust huvist visuaalsete/ verbaalsete kujundite tekitatud tunnete vastu eraldiseisev meetod, mis suudab luua viljaka sideme keele ja keeletu taju vahel. Artikli lõpuosas pakutakse välja 'kehalise reaalsusefekti' mõiste, esitades afektiivse lugemisnäite kahest sarnasest stseenist, mida Barthes'i ise karjääri varases ja hilises järgus tõlgendanud oli. 